\title{
VESTIBULAR REHABILITATION
}

\section{Clinical benefits to patients with Parkinson's disease}

\author{
Bianca Simone Zeigelboim', Karlin Fabianne Klagenberg", Hélio A. Ghizoni Teive ${ }^{3}$, \\ Renato Puppi Munhoz ${ }^{3,4}$, Jackeline Martins-Bassetto ${ }^{2}$
}

\begin{abstract}
Objective: To evaluate the effectiveness of the vestibular rehabilitation (VR) exercises by means of an assessment before and after the application of the Brazilian version of the Dizziness Handicap Inventory (DHI) questionnaire. Method: Twelve patients were studied, the following procedures were carried out: anamnesis, otorhinolaryngological and vestibular evaluation, and the application of the DHI before and after the VR. Results: Clinically resting tremors and subjective postural instability were the motor complaints most frequently associated with complaints of vertigo in 12 cases (100\%); in the vestibular exam, all the patients presented abnormalities, frequently from the uni and bilateral peripheral vestibular deficiency syndromes in 10 cases (83.3\%); there was significant improvement in the physical, functional and emotional aspects of the DHI after the completion of the VR. Conclusion: The VR following the Cawthorne and Cooksey protocol were shown to be useful in managing subjective complaints of several aspects evaluated in this protocol.
\end{abstract}

KEY WORDS: Parkinson's disease, rehabilitation, vestibular function tests.

\section{Reabilitação vestibular: utilidade clínica em pacientes com doença de Parkinson}

Resumo - Objetivo: Avaliar a eficácia dos exercícios de reabilitação vestibular (RV) por meio de avaliação pré e pós-aplicação da versão brasileira do questionário Dizziness Handicap Inventory (DHI). Método: Estudou-se 12 pacientes e realizaram-se os seguintes procedimentos: anamnese, avaliação otorrinolaringológica, vestibular e aplicação do DHI pré e pós RV. Resultados: Do ponto de vista clínico, o tremor de repouso e a instabilidade postural subjetiva foram às queixas motoras mais freqüentes associadas às queixas de vertigem em 12 casos (100\%); no exame vestibular, todos os pacientes apresentaram anormalidades, com frequeência das sindromes vestibulares periféricas deficitárias uni e bilaterais em 10 casos (83,3\%); houve melhora significativa dos aspectos fissico, funcional e emocional do $\mathrm{DH}$ após a realização da RV. Conclusão: A RV seguindo o protocolo de Cawthorne e Cooksey mostrou-se útil no manejo de queixas subjetivas de diversos aspectos avaliados neste protocolo.

PALAVRAS-CHAVE: doença de Parkinson, testes de função vestibular, reabilitação.

The aging process manifests itself by a decline in the functions of several organs in a linear fashion in function of the time with the exact transition point not definable, as in other phases. It is observed that at the end of the third decade, anatomofunctional alterations associated with aging become distinct'. With an increase in life expectancy observed globally, the prevalence of degenerative diseases such as Parkinson's disease (PD) and Alzheimer's disease has become increasingly significant ${ }^{2}$.
PD is characterized by a combination of at least 2 of the three cardinal signs of Parkinson's syndrome: resting tremors, rigidity and bradykinesia ${ }^{3}$. In PD, for more than two decades, sensory dysfunctions with variable intensities in smell, visual perception of colours and contrasts, proprioception and motor control have been described ${ }^{4}$. The characteristic functional abnormality is dopaminergic deficit secondary to the degeneration of the substantia nigra pars compacta ${ }^{5}$. The specific cause of this degeneration

\footnotetext{
'Otoneurology Sector, Graduate Program in Communication Disorders, University Tuiuti of Paraná, Curitiba PR, Brazil, Audiologist, Ph.D. in Communication Disorders, Professor and Coordinator of the Graduate Program in Communication Disorders; ${ }^{2}$ Otoneurology Sector, Graduate Program in Communication Disorders, University Tuiuti of Paraná, Curitiba PR, Brazil, Audiologist, M.S., Curitiba PR, Brazil; ${ }^{3}$ Neurology Service, Department of Neurology, Hospital de Clinicas, Federal University of Paraná, Curitiba PR, Brazil, Neurologist; ${ }^{4}$ State of Parana Parkinson Association, Curitiba PR, Brazil, Neurologist. Financing: National Council of Scientific and Technological Development (CNPQ).
}

Received 4 September 2008, received in final form 24 November 2008. Accepted 11 February 2009.

Dra. Bianca Simone Zeigelboim - Rua Gutemberg 99 /9 andar - 80420-030 Curitiba PR - Brasil.E-mail: bianca.zeigelboim@utp.br 
remains unknown and is probably multifactorial, including genetic predisposition, oxidative stress and environmental factors, among others ${ }^{6}$. In the geriatric population, where the majority of the PD cases occur, there is a vulnerability in the ability of the central nervous system to process vestibular, visual and proprioceptive signs which are responsible for the maintenance of balance, with a decrease in the capacity to modify the postural adaptive reflexes. Symptoms such as vertigo and the difficulty to balance are part of these abnormalities ${ }^{7}$. Postural stability depends on the integrity of the vestibular system (vestibular labyrinth, vestibulocochlear nerve, nuclei, channels and interrelations in the central nervous system), the somatosensory system (sensory receptors located in the tendons, muscles and articulations) and vision ${ }^{7}$. The vestibular labyrinth is responsible for the balance and position of the body in space. Complaints of vertigo and postural instability of vestibular origin can occur at both peripheral and central levels ${ }^{8}$. Individuals above 75 years manifest vertigo as the most marked symptom and in these cases, the alterations of postural control are important causes of an increase in the risk of falls and in the morbimortality in this population ${ }^{9-11}$.

The leading forms of treatment for vestibular dysfunctions are medical, surgical and vestibular rehabilitation $(V R)^{12}$. VR acts in a physiological manner on the vestibular system, and is a therapeutic remedy which involves proprioceptive and vestibular visual stimuli, with the intention of maintaining the corporal balance of patients with vertiginous symptoms ${ }^{12,13}$. It is a procedural proposal based on central mechanisms of neuroplasticity known as adaptation, familiarization and substitution for obtaining vestibular compensation ${ }^{12,13}$. The VR exercises seek to improve the vestibulovisual interaction during cephalic movement, increase the static and dynamic postural stability in conditions which generate conflicting sensory information and reduce individual sensitivity to cephalic movement ${ }^{12-14}$. VR is an important method in the therapeutic approach for patients with postural instability, which has opened new horizons in the oto-neurologic clinic over the past few decades.

The objective of our study was to evaluate the effectiveness of VR exercises by means of an assessment before and after the application of the Brazilian version of the Dizziness Handicap Inventory (DHI) questionnaire.

\section{METHOD}

Twelve patients ( 7 female) were evaluated with a diagnosis of PD according to the criteria of the Queen Square Brain Bank and followed by the Parkinson's Disease Association for Paraná State (APPP). All patients were selected because of complaints of vertigo, with mean age $70.83 \pm 4.57$ years. Everyone was evaluated in the Laboratory of Otoneurology of the Tuiuti University of Paraná. Patients with significant visual, psychiatric, rheumato- logical, and musculoskeletal vulnerabilities or any abnormality that prevented completion of the evaluation and the VR, were not included in the study.

The patients were submitted to the following procedures:

Anamnesis - A questionnaire was administered with emphasis on otoneurological signs and symptoms.

Otorhinolaryngological evaluation - Administered with the objective of excluding any other alteration that might interfere with the exam.

Vestibular evaluation - The patients were submitted to the following tests which constitute the vestibular exam:

\section{Not Logged}

Positional nystagmus and vertigo and spontaneous and semispontaneous nystagmus in the frontal plane and at 30 degrees deviation from the plane of the four cardinal points were all studied.

\section{Logged}

For the completion of the vectoelectronystagmography (VENG) a thermosensitive Berger apparatus, model VN316 was used with three channels for registration. The Ferrante decreasing pendulous rotative chair was used together with a Neurograff visual stimulator, model EV VEC and a Neurograff air oto calorimeter, model NGR 05. The following ocular and VENG labyrinthine tests were performed according to the criteria proposed by the Mangabeira-Albernaz et al. ${ }^{15}$.

Calibration of ocular movements; analysis of spontaneous and semi-spontaneous nystagmus; analysis of pendulous tracking; analysis of optokinetic nystagmus; analysis of pre and post rotative nystagmus to the decreasing pendulous rotative test; analysis of pre and post caloric nystagmus.

When examination was completed, patients were informed about the VR program.

\section{Implementation of the Dizziness Handicap}

Inventory questionnaire (DHI), Brazilian version

This questionnaire originally designed by Jacobson et al. ${ }^{16}$ was culturally adapted to the Brazilian population by Castro ${ }^{17}$. The questionnaire was administered before and after completion of the VR exercises, assessing the level of disability related to dizziness in the activities of daily living and evaluating the emotional, functional and physical aspects totaling 25 topics. The responses allowed were "yes", equivalent to a score of 4 "sometimes", equivalent to 2 and "no", equivalent to 0 . The total scores ranged from 0 to 100 points, with the closer the value to 100 , the greater the extent of disability caused by dizziness in the patient's activities of daily living.

\section{VR Protocol of Cawthorne and Cooksey ${ }^{18,19}$}

The exercises were administered during three months, twice a week, followed by an assimilation of repetitions at home ${ }^{18,19}$. The objective of this protocol was the improvement of static and dynamic balance function, with a recovery of spatial coor- 
Table 1. Frequency of symptoms of 12 patients with Parkinson's disease.

\begin{tabular}{lcc}
\hline Symptoms & $\begin{array}{c}\text { Number of } \\
\text { patients }\end{array}$ & $\begin{array}{c}\text { Frequency } \\
(\%)\end{array}$ \\
\hline Resting tremor & 12 & 100 \\
Vertigo & 12 & 100 \\
Subjective postural instability & 10 & 83.3 \\
Hearing loss & 7 & 58.3 \\
Tinnitus & 6 & 50.0 \\
Deviation in gait & 3 & 25.0 \\
Falls & 3 & 25.0 \\
Hyper sensitivity to intense sounds & 2 & 17.0 \\
Ear pressure & 2 & 17.0 \\
Difficulty to understand speech & 1 & 8.3 \\
Sensations of floating & 1 & 8.3 \\
Anxiety & 1 & 8.3 \\
Depression & 1 & 8.3 \\
\hline
\end{tabular}

dination. This protocol was selected because of its easy administration and allowed group performance.

Patients were oriented that they would be working within a level of minimal discomfort, and that the exercises could prompt symptoms which would activate the natural mechanisms of compensation. Follow-up sessions took place to make corrections, if necessary and offer guidance.

\section{Statistical method}

The descriptive analysis of the data from the anamnesis and the vestibular evaluation was performed. For an analysis of the data from the $\mathrm{DHI}$ questionnaire, Brazilian version, the Student $\mathrm{t}$
Table 2. Frequency of abnormal findings in the vestibular evaluation in 12 patients with Parkinson's disease.

\begin{tabular}{lcc}
\hline Findings & $\begin{array}{c}\text { Number of } \\
\text { patients }\end{array}$ & $\begin{array}{c}\text { Frequency } \\
\text { (\%) }\end{array}$ \\
\hline Unilateral vestibular hyporeflexia & 5 & 41.6 \\
Bilateral vestibular hyporeflexia & 5 & 41.6 \\
Unilateral vestibular hyperreflexia & 1 & 8.3 \\
Bilateral vestibular hyperreflexia & 1 & 8.3 \\
Positional vertigo and/or nystagmus & 1 & 8.3 \\
Study of spontaneous & 1 & 8.3 \\
open-eye nystagmus & & \\
Asymmetry of post-rotative nystagmus & 1 & 8.3 \\
Calibration of irregular & 1 & 8.3 \\
ocular movement & & \\
\hline
\end{tabular}

test was administered and a 0.05 or $5 \%$ level of significance was adopted to rule out the nullity hypothesis.

This study was approved by the Committee of Institutional Ethics, ruling no. 008/2005 all patients gave informed consent.

\section{RESULTS}

Clinically, we observed that the most common motor complaints were resting tremors and the subjective postural instability, associated with complaints of vertigo as shown in Table 1. Concerning the evaluation of the vestibular function, alterations were verified in all 12 patients $(100 \%)$, with a prevalence of unilateral and bilateral hyporreflexia in 10 patients (83.3\%) as shown in Table 2 . The results of the vestibular exam established 5 cases (41.7\%) of unilateral deficient peripheral vestibular syndrome, 4 cases (33.4\%) of bilateral deficient peripheral vestibular

Table 3. Evaluation of the physical, functional and emotional aspects pre and post treatment.

\begin{tabular}{|c|c|c|c|c|c|c|c|c|}
\hline \multirow[b]{2}{*}{ Patient } & \multicolumn{2}{|c|}{ Physical } & \multicolumn{2}{|c|}{ Functional } & \multicolumn{2}{|c|}{ Emotional } & \multicolumn{2}{|c|}{ Total } \\
\hline & Pre & Post & Pre & Post & Pre & Pos & Pre & Post \\
\hline 1 & 2 & 4 & 6 & - & 8 & - & 16 & 4 \\
\hline 2 & 16 & 2 & 20 & 4 & 8 & - & 44 & 6 \\
\hline 3 & 6 & 2 & 8 & 4 & 8 & 6 & 22 & 12 \\
\hline 4 & 8 & - & 12 & - & 10 & - & 30 & - \\
\hline 5 & - & - & 8 & - & - & - & 8 & - \\
\hline 6 & 4 & - & 2 & - & 2 & - & 8 & - \\
\hline 7 & 2 & - & 10 & 4 & 12 & 2 & 24 & 6 \\
\hline 8 & 12 & 6 & 6 & 2 & - & - & 18 & 8 \\
\hline 9 & 20 & 10 & 12 & 6 & 4 & 2 & 36 & 18 \\
\hline 10 & 14 & 2 & 6 & - & 6 & - & 26 & 2 \\
\hline 11 & 2 & - & 4 & - & - & - & 6 & - \\
\hline 12 & 20 & 10 & 8 & 4 & 20 & 4 & 48 & 18 \\
\hline Mean & 8.8 & 3 & 8.5 & 2 & 6.5 & 1.2 & 23.8 & 6.2 \\
\hline SD & 7.3 & 3.8 & 4.7 & 2.3 & 5.9 & 2.0 & 13.8 & 6.7 \\
\hline
\end{tabular}

SD: standard deviation. 
syndrome, 1 case $(8.3 \%)$ of unilateral irritative peripheral vestibular syndrome 1 case $(8.3 \%)$ of bilateral deficient central vestibular syndrome and 1 case $(8.3 \%)$ of bilateral irritative central vestibular syndrome.

The analysis of the DHI questionnaire, Brazilian version, showed significant improvement was observed in the marks total with variation from 6 to 48 , mean 23.8, and standard deviation 13.8 in the pre-treatment and variation from 0 to 18 points, mean 6.2, and standard deviation 6.7 in the post-treatment, as shown in Table 3. The Student $t$ test comparing the evaluations before and after RV showed $p$ values ( 0.001960 physical; 0.000129 functional) and ( 0.000122 emotional). All were significant, considering the $5 \%$ level of significance.

In the analyses of the pre and post-treatment means of the physical, functional and emotional aspects, a decrease and a consequent improvement were observed in all the aspects evaluated. In the physical aspect the mean varied from 8.8 to 3 , the functional aspect from 8.5 to 2 and the emotional aspect from 6.5 to 1.2 .

\section{DISCUSSION}

Imbalance, gait disturbances and postural abnormalities are common in PD. The main symptom resulting from vestibular system dysfunction in the elderly is rotatory dizziness, which may or may not be associated with other types of dizziness ${ }^{12}$. In the current study it can be verified, from a clinical point of view, that the most common motor complaints were resting tremors and subjective postural instability, associated with vertigo.

The aging of the sensory systems, especially vision, proprioception, plantar pressure receptors and internal ear functioning, in all system levels produces a neuronal loss that begins in the sixth decade and accelerates after $70^{20}$. With respect to the vestibular evaluation, abnormalities of the peripheral vestibular system were observed in 10 patients $(83.3 \%)$ and of the central vestibular system in 2 patients (16.7\%). The prevalence of alterations in the peripheral vestibular system has been observed in several previous studies ${ }^{20,21}$. The abnormal findings to the VENG, namely hyporeflexia, have already been reported in similar studies ${ }^{21}$ in PD patients and healthy elderly subjects. The reduction in the response to the caloric tests was perceived as one of the modifications of the vestibular system in relation to the aging process ${ }^{22}$. Several studies ${ }^{22}$ mention the loss of ciliated cells of the ampullary crests and the maculae, decline in the number of neurons of the vestibular ganglion, degeneration of the otoconia, decrease in the labyrinthine blood flow, progressive depression of neural stability, reduction in the compensation capacity of the vestibulo-ocular (responsible for maintaining vision stable during cephalic movement) and vestibulospinal (responsible for corporal sta- bilization) reflexes, which contribute to a decrease in the speed of pursuit movements and to rotational and caloric hypoactivity of the vestibular system, at both the peripheral and central level.

Considering the $\mathrm{DHI}$ as a measure for specific conditions and which evaluates the health of individuals with vestibular disorders, the Brazilian version was administered before and after VR therapy. Significant improvement was detected in the three aspects evaluated and the analyses of the pre and post-treatment mean values typified symptomatologic improvements in all the patients. VR is a therapeutic process which seeks to accelerate the mechanisms of central compensation by means of neuronal plasticity with the execution of repetitive exercis$\mathrm{es}^{23}$. In our findings, the hypothesis that VR exercises can promote a decrease in vestibular symptomatology has been reinforced, with the exercises identified as strong allies in the treatment of peripheral dysfunctions.

Significant improvements were observed in our study using the parameters described in concurrence with previous studies ${ }^{24,25}$, that also used the Cawthorne and Cooksey ${ }^{18,19}$ exercises. Subjective and objective improvement was also demonstrated in similar studies of the authors ${ }^{22-26}$. Additionally we observed an improvement in parameters of quality of life in all aspects.

In conclusion, the VR following the Cawthorne and Cooksey protocol were shown to be useful in managing subjective complaints of several aspects evaluated in this protocol.

\section{REFERENCES}

1. Cançado FAX, Horta ML. Envelhecimento cerebral. In: Freitas EV, Py L, Neri AL (Eds). Tratado de geriatria e gerontologia. Rio de Janeiro: Guanabara Koogan, 2002:112-127.

2. Westerberg BD, Roberson JB, Stach BA, Silverberg GD, Heit $\mathrm{GH}$. The effects of posteroventral pallidotomy on balance function in patients with Parkinson's disease. Stereotact Funct Neurosurg 2002;79:75-87.

3. Sekeff-Salem FA, Barbosa ER. Diagonostic pitfalls in Parkinson's disease. Arq Neuropsiquiatr 2007;65:348-351.

4. Quagliato LB, Viana MA, Quagliato EMAB, Simis S. Alterações no olfato na doença de Parkinson. Arq Neuropsiquiatr 2007;65:647-652.

5. Teive HAG. Etiopatogenia da doença de parkinson. In: Menezes MS, Teive HAG (Eds). Doença de Parkinson. Rio de Janeiro: Guanabara Koogan, 2003:33-37.

6. Smeltzer SC, Bare BG.Tratamento de paciente com distúrbio neurológico. In: Smeltzer SC, Bare BG (Eds). Tratado de enfermagem médico-cirúrgica. Rio de Janeiro: Guanabara Koogan, 2002:1653-1655.

7. Ganança FF, Castro ASO, Branco FC, Natour J. Interferência da tontura na qualidade de vida de pacientes com síndrome vestibular periférica. Rev Bras Otorrinolaringol 2004;70:94-101. 
8. Jurkiewicz AL, Zeigelboim BS, Mangabeira-Albernaz PL. Alterações vestibulares em processos infecciosos do sistema nervoso central. Distúrb Comum 2002;14:27-48.

9. Zeigelboim BS, Jurkiewicz AL, Fukuda Y, Mangabeira-Albernaz PL. Alterações vestibulares em doenças degenerativas do sistema nervoso central. Pró-Fono Rev Atual Cient 2001;13: 263-270.

10. Smiley-Oyen AL, Cheng HY, Latt LD, Redfern MS. Adaptation of vibration-induced postural sway in individuals with Parkinson's disease. Gait Posture 2002;16:188-197.

11. Simoceli L, Bittar RMS, Bottino MA, Bento RF. Perfil diagnóstico do idoso portador de desequilíbrio corporal: resultados preliminares. Rev Bras Otorrinolaringol 2003;69:772-777.

12. Ganança FF, Ganança CF. Reabilitação vestibular: princípios e técnicas. In: Ganança MM, Munhoz MSL, Caovilla HH, Silva MLG (Eds). Estratégias terapêuticas em otoneurologia. $1^{\text {a }}$ Ed. São Paulo: Atheneu, 2001:33-54.

13. Amá LAG, Oliveira GC. Reabilitação vestibular - nossa experiência. Rev Bras Otorrinolaringol 1993;60:113-116.

14. Rezende CR, Taguchi CK, Almeida K, Fujita RR. Reabilitação vestibular em pacientes idosos portadores de vertigem posicional paroxístitca benigna. Rev Bras Otorrinolaringol 2003;69: 34-38.

15. Mangabeira-Albernaz PL, Ganança MM, Pontes PAL. Modelo operacional do aparelho vestibular. In: Mangabeira-Albernaz PL, Ganança MM (Eds). Vertigem. $2^{\text {a }}$ Ed. São Paulo: Moderna, 1976:29-36.

16. Jacobson GP, Newman CW. The development of the dizzi- ness handicap inventory. Arch Otolaryngol Head Neck Surg 1990;152:386-391.

17. Castro ASO, Gazzola JM, Natour J, Ganança FF. Versão brasileira do dizziness handicap inventory. Pró-Fono Rev Atual Cient 2007;19:97-104.

18. Cawthorne T. The physiological basis of head exercises. J Chart Soc Physiother 1944;30:106-107.

19. Cooksey FS. Rehabilitation in vestibular injuries. Proc Royal Soc Méd 1946;39:273-278.

20. Mota PHM, Franco ES, Monteiro Pinto ES, Arieta AM. Estudo do equilíbrio no idoso por meio da electronistagmografia. Acta Awho 2002;21:1-12.

21. Gushikem P, Caovilla HH, Ganança, MM. Avaliação otoneurológica em idosos com tontura. Acta Awho 2002;21:1-25.

22. Silveira SR, Taguchi CK, Ganança FF. Análise comparativa de duas linhas de tratamento para pacientes portadores de síndromes vestibulares periféricas com idade superior a sessenta anos. Acta Awho 2002;21:14-31.

23. Cesarani A, Alpini D, Monti B, Raponi G. The treatment of acute vertigo. Neurol Sci 2004;24:26-30.

24. Shepardn SAL.Vestibular and rehabilitation therapy. Ann Otol Rhinol Laryngol 1993;102:198-205.

25. O'reilly RC, Elford B, Slater R. Efectiveness of particle repositioning maneuvers in subtypes of benign paroxysmal positional vertigo. Laryngoscope 2000;110:1385-1388.

26. Pavan K, Marangoni BEM, Schimidt KB, et.al. Reabilitação vestibular em pacientes com esclerose múltipla remitente-recorrente. Arq Neuropsiquiatr 2007;65:332-335. 